\title{
ITS and Electronic Toll Systems
}

\author{
L. Bína*, H. Nováková, M. Jánešová \\ Faculty of Transportation Sciences, Czech Technical University in Prague, Prague, Czech Republic \\ *Corresponding author: bina@fd.cvut.cz
}

DOI: $10.2478 / \mathrm{v} 10158-012-0018-\mathrm{Z}$

\begin{abstract}
In the paper the Czech toll system and its future are presented. The paper describes also the ITS solutions for use of the possibilities of electronic toll system for reducing congestion on the highway network of the Czech Republic, as well as solutions of differentiated toll tariffs and their impact on changes of fleet towards ecological vehicles with EURO V and higher engines. In conclusion, it is presented a new certified methodology used to determine the toll tariffs in terms of EU directives.
\end{abstract}

KEY WORDS: toll system, traffic regulation, congestions.

\section{INTRODUCTION}

In response to the situation in the surrounding states, fees started to be charged for the road network in the Czech Republic in 1995 and highway vignettes were introduced for that purpose. The motive was to secure further funds for the development of mainly the highway network and for the prospective solution concerning related applications.

Even when in 2007 an electronic toll system involving output-related payments based on the distance covered within the network of highways, expressways and selected sections of the roads of the $1^{\text {st }}$ class was introduced in the Czech Republic for vehicles in the weight category of $12 \mathrm{t}$ and more, the highway vignettes remained for the other categories of vehicles.

With regard to the interoperability of the toll systems within the EU, there is a European Commission Decision of 6 October 2009 on the definition of the European Electronic Toll Service and its technical elements (EETS). According to this decision, the EETS system should be implemented in the EU within 3 years from the year 2009.

\section{IMPLEMENTATION OF AN ELECTRONIC TOLL SYSTEM (ETS) IN THE CZECH REPUBLIC}

In the period of the years 2002 and 2003 and other years, various studies and experts's statements were prepared and works and opinions of experts from the Ministry of Transport of the Czech Republic and other institutions and scientific centres were presented on electronic toll.

Already at the time when the task was defined, it was emphasized that the money collected from the output-related payment system as well as the money collected from the time system (vignettes) would be used solely for reconstruction of, repairs to and construction of the road 
network, including its development, also connected with the issues of traffic regulation, information, telematics and safety. The preparation of the implementation of the toll system was also based on the European Directives - particularly 1999/62/EC and 2006/38/EC, and the 2004/52/EC directive (interoperability) was also continued to apply to the Czech Republic.

The history of the implementation and changes in the Electronic Toll System (ETS) in the Czech Republic is in Table 1.

Table 1: The history of changes in the Electronic Toll System in the Czech Republic.

(Source: Ministry of Transport of the Czech Republic)

\begin{tabular}{|l|l|}
\hline Date & Change \\
\hline 1.4 .2006 & Closure of the tender for the toll system - contract signature. \\
\hline 1.1 .2007 & Introduction of tolls on motorways and expressways. \\
\hline 1.1 .2008 & Introduction of tolls on selected sections of 1st class roads. \\
\hline 1.1 .2010 & Extension of toll on vehicles with weight higher than 3.5 tons. \\
\hline 1.2 .2010 & $\begin{array}{l}\text { Introduction of increase in toll rates by } 50 \% \text { on Friday from 3pm to 9pm included, which was compensated by } \\
\text { decrease in rates during other hours of the day and week. The result was a reduction of traffic on tolled } \\
\text { communications by about 11\% in the period of increased toll rates. }\end{array}$ \\
\hline 1.1 .2011 & $\begin{array}{l}\text { Increase in toll rates by 19\% and introduction of an independent emissions group EURO V, which is not subject } \\
\text { to an increase in toll rates. Reduction of increased toll rates at selected Friday hours to } 40 \% \text { as compensation } \\
\text { for carriers. }\end{array}$ \\
\hline 1.9 .2011 & $\begin{array}{l}\text { Introduction of individual reduced toll rates for buses. Toll rates for buses are differentiated only by the } \\
\text { emission class and are not increased on Friday. }\end{array}$ \\
\hline 1.1 .2012 & Estimated increase in toll rates by approximately $25 \%$, except buses and vehicle class EURO V and higher. \\
\hline
\end{tabular}

Organisation of the construction and operation management of ETC in the Czech Republic:

Investor/Buyer: Ministry of Transport of the Czech Republic (MD ČR)

Operator: Road and Motorway Directorate of the Czech Republic (̌̌SD ČR)

Mobile Enforcement: General Directorate of Customs (GǨC ČR)

Project Manager: Consortium of Deloitte Czech Republic and Bovis Lend Lease, a.s.

General Contractor and operator of services of ETC: Kapsch Consortium. Kapsch has provided the complete operation services for the Czech Republic since January 2007. The total term of the contract is 10 years.

Auditor: Logica

\section{THE RESULTS OF THE OPERATION OF THE TOLL SYSTEM IN THE CZECH REPUBLIC}

Table 2 shows the development of the toll road network in the Czech Republic with the prognosis of development until 2017. The same table shows the reality and forecast of the revenues from the toll road network ETS. The revenues from time coupons for vehicles less than 3.5 tons are not included in these calculations. In the Figure 1 there is a map of the charged road network in the Czech Republic in the 2012. In Table 3 there are applicable data of toll tariffs on toll road network of the Czech Republic in 2012. 
Table 2: Survey of total toll income and total length of toll roads development.

(Bina et al., 2011)

Exchange rate of 1 EUR = 24,445 - Czech National Bank, 14. 9.2012

\begin{tabular}{|c|c|c|c|c|c|c|c|c|c|c|c|c|}
\hline & & 2007 & 2008 & 2009 & 2010 & 2011 & 2012 & 2013 & 2014 & 2015 & 2016 & 2017 \\
\hline Total toll income & [mil. CZK] & 5433 & 6012 & 5431 & 6422 & 7994 & 9571 & 10069 & 10334 & 10606 & 10885 & 11352 \\
\hline Toll of vehicles above $3,5 \mathrm{t}$ & [mil. CZK] & 5433 & 6012 & 5431 & 6422 & 7994 & 9571 & 10069 & 10334 & 10606 & 10885 & 11352 \\
\hline Motorways and expressways & [mil. CZK] & 5433 & 5700 & 5173 & 6129 & 7659 & 9170 & 9658 & 9912 & 10173 & 10440 & 10896 \\
\hline 1st class roads & [mil. CZK] & & 312 & 258 & 293 & 335 & 401 & 411 & 422 & 433 & 445 & 456 \\
\hline Toll of vehicles bellow 3,5 tons & [mil. CZK] & 0 & 0 & 0 & 0 & 0 & 0 & 0 & 0 & 0 & 0 & 0 \\
\hline Number of distributed OBU & & 252628 & 351124 & 398079 & 466796 & & & & & & & \\
\hline & & & & & & & & & & & & \\
\hline Motorways and expressways & [km] & 937 & 993 & 1034 & 1149 & 1368 & 1391 & 1415 & 1440 & 1465 & 1490 & 1516 \\
\hline \begin{tabular}{|l|l|} 
1st class roads \\
\end{tabular} & [km] & 0 & 180 & 198 & 196 & 196 & 196 & 196 & 196 & 196 & 196 & 196 \\
\hline Total lenght of toll roads & [km] & 937 & 1173 & 1232 & 1345 & 1368 & 1391 & 1415 & 1440 & 1465 & 1490 & 1516 \\
\hline
\end{tabular}

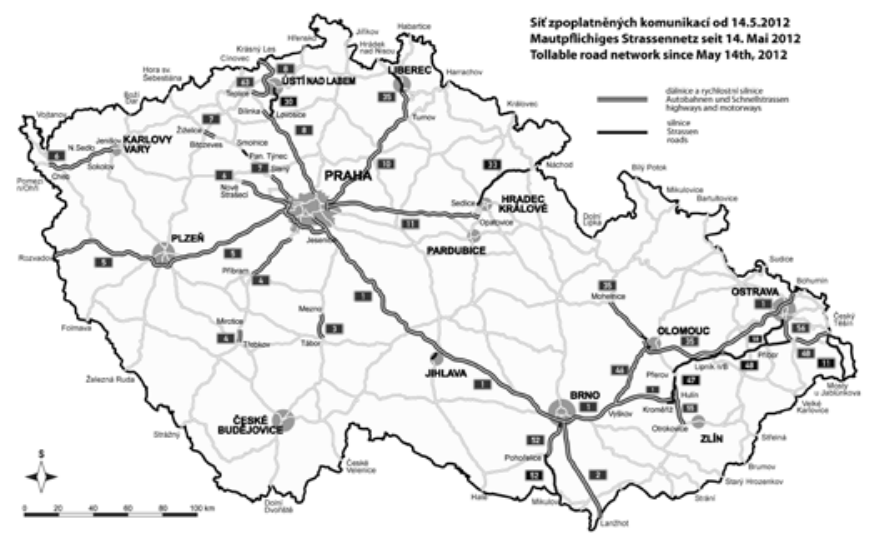

Figure 1: Map of the charged road network in the Czech Republic in 2012.

(Source: Road and Motorway Directorate of the Czech Republic)

Table 3: Toll rates table 2012

(Source: Road and Motorway Directorate of the Czech Republic)

Exchange rate of 1 EUR = 24,445 - Czech National Bank, 14. 9. 2012

\begin{tabular}{|c|c|c|c|c|c|c|c|c|c|}
\hline \multicolumn{10}{|c|}{ Toll Rates for Trucks [CZK/km] in most of weekdays } \\
\hline & \multicolumn{3}{|c|}{ Emission Class EURO 0-II } & \multicolumn{3}{|c|}{ Emission Class EURO III-IV } & \multicolumn{3}{|c|}{ Emission Class EURO V+ } \\
\hline \multirow[t]{2}{*}{2012} & \multicolumn{9}{|c|}{ Axles } \\
\hline & 2 & 3 & $4+$ & 2 & 3 & $4+$ & 2 & 3 & $4+$ \\
\hline Highways & 3,34 & 5,67 & 8,24 & 2,61 & 4,45 & 6,44 & 1,67 & 2,85 & 4,12 \\
\hline Roads & 1,58 & 2,74 & 3,92 & 1,23 & 2,14 & 3,06 & 0,79 & 1,37 & 1,96 \\
\hline
\end{tabular}

\begin{tabular}{|c|c|c|c|c|c|c|c|c|c|}
\hline \multicolumn{10}{|c|}{ Toll Rates for Trucks [CZK/km] Friday 15:00 - 21:00 } \\
\hline & \multicolumn{3}{|c|}{ Emission Class EURO 0-II } & \multicolumn{3}{|c|}{ Emission Class EURO III-IV } & \multicolumn{3}{|c|}{ Emission Class EURO V+ } \\
\hline \multirow[t]{2}{*}{2012} & \multicolumn{9}{|c|}{ Axles } \\
\hline & 2 & 3 & $4+$ & 2 & 3 & $4+$ & 2 & 3 & $4+$ \\
\hline Highways & 4,24 & 8,10 & 11,76 & 3,31 & 6,35 & 9,19 & 2,12 & 4,06 & 5,88 \\
\hline Roads & 2,00 & 3,92 & 5,60 & 1,56 & 3,06 & 4,38 & $1,-$ & 1,96 & 2,80 \\
\hline
\end{tabular}

\begin{tabular}{|c|c|c|c|}
\hline \multicolumn{3}{|c|}{ Toll Rates for Buses [CZK/km] } \\
\hline \hline 2012 & Emission Class EURO 0-II & Emission Class EURO III-IV & Emission Class EURO V+ \\
\hline $\begin{array}{l}\text { Highways } \\
\text { Roads }\end{array}$ & 1,38 & $1,-$ & 0,80 \\
\hline
\end{tabular}


In Figure 2 and 3 behaviour of the traffic volumes in 2011 (July-August), by the type of roads (Figure 2) and by vehicle category (Figure 3) are shown.

As in previous years, $92 \%$ of the traffic volume is on highways and expressways. The remaining $8 \%$ of the traffic volume is carried out on selected sections of $1^{\text {st }}$ class roads. Traffic volumes are relatively stable, although there was an increase in 2010 owing to the expansion of the range of vehicles that are subject to the toll and also in recent months following the opening of the heavily used ring road around Prague. It is interesting to notice that the monthly traffic volumes are created by around 190 thousand vehicles, even though the number of registered vehicles exceeds 500 thousand.

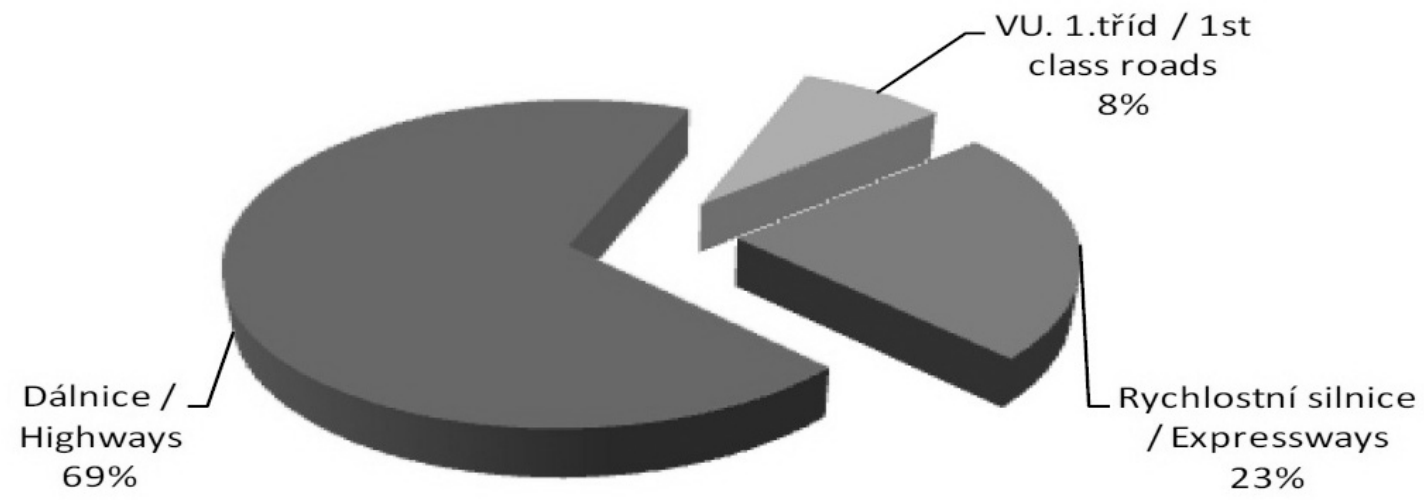

Figure 2: Traffic volume by type of roads (1.-8./2011).

(Source: DWH of the E-toll System/DWH - Data Warehouse of the E-toll System)

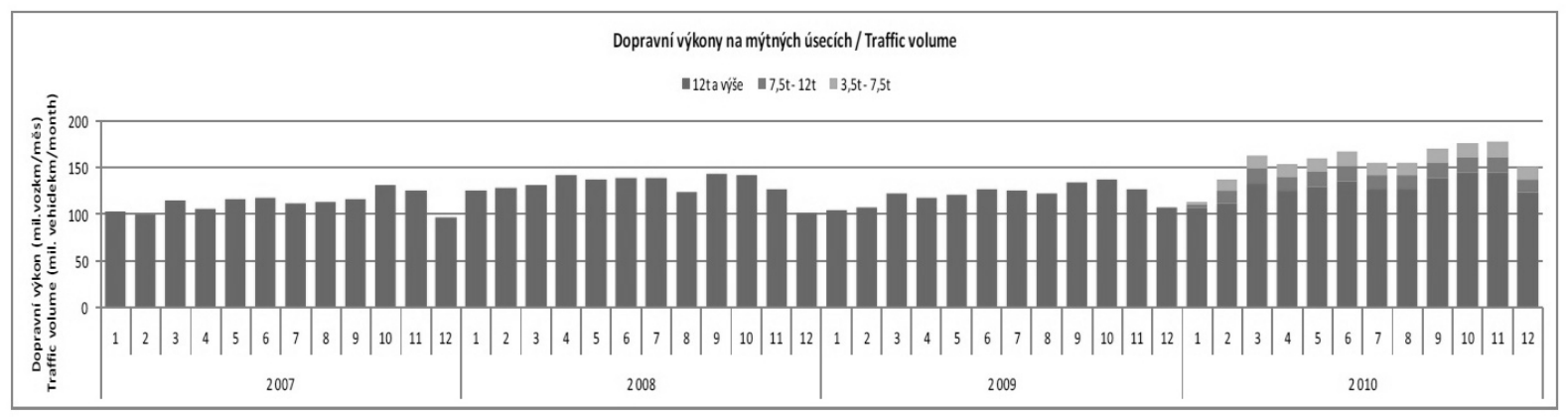

Figure 3: Development of traffic volume in years 2007-2010.

(Source: DWH of the E-toll System)

In the monitored period, the traffic volume of vehicles registered in the toll system was approximately the same as we can see for vehicles weighing over 12 tons on the tolled sections that were put in operation on 1 January 2007. In 2009 a moderate downturn can be seen as a result of the economic cycle, followed by a slow recovery in 2010. Under these assumptions, in period from year 2010 till 2017, weighted average tolls of heavy goods vehicles on motorways, expressways and tolled $1^{\text {st }}$ class roads are always below the maximum weighted average toll (following Figure 4). 


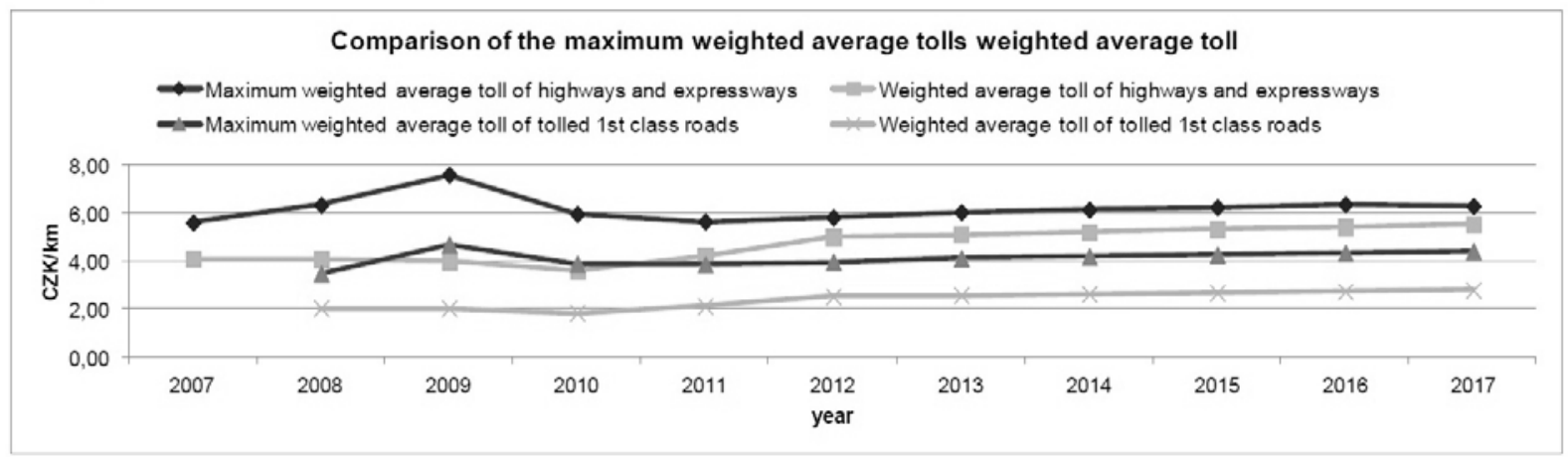

Figure 4: Weighted average tolls of heavy goods vehicles on motorways, expressways and tolled $1^{\text {st }}$ class roads till 2017.

(Bina et al., 2011)

(Exchange rate of 1 EUR = 24,445 - Czech National Bank, 14.9.2012)

\section{ANOTHER MAJOR APPLICATION WILL BE INTRODUCTION OF DIFFERENTIATED TOLL IN THE AFTERNOON HOURS ON FRIDAY}

Internalisation of the external costs is the main priority of the transport policy of the EU. The basic principle is to charge the vehicles, which have a negative impact on the environment and health and which generate a noise burden on the surroundings of the roads and congestions. One of the works on the topic of charging transport externalities in road transport is the work of the Joint Research Centre - JRC European Commission.

In the Czech Republic, it was necessary to address the situation concerning the restriction of operation of vehicles in the Czech Republic. Section 43 of the Act No. 361/2000 Sb. (Sb. = Collection of Laws) on the traffic on roads and on changes to some Acts (the Road Traffic Act) defines the scope and the periods of restrictions on the travel of some vehicles. Trucks and special automobiles and special vehicles with the maximum admissible weight exceeding $7,500 \mathrm{~kg}$ and trucks and special automobiles and special vehicles with the maximum admissible weight exceeding $3,500 \mathrm{~kg}$ with an attached trailer vehicle are prohibited from driving on a highway and a $1^{\text {st }}$ class road:

- On Sundays and on public holidays as defined in special legislation (hereinafter referred to as the "rest day") from 13.00 to 22.00 .

- On Saturdays in the period from 1 July to 31 August from 7.00 to 13.00 .

- On Fridays in the period from 1 July to 31 August from 17.00 to 21.00.

Within the governmental and parliamentary activities and a number of negotiations with road forwarders and their professional organisations, a proposal for higher charges for the Friday trips of vehicles weighing more than 3.5 tons on Friday afternoons was accepted as a measure to reduce congestions on the highway network of the Czech Republic during Friday afternoon hours on an all-year-round basis and on the following conditions:

- The existing legislation restrictions on the vacation traffic remain in effect.

- On Fridays from 15.00 to 21.00 , the toll rates are increased by $25 \%$ for vehicles with 2 axles and by $50 \%$ for vehicles with 3, 4 and more axles, on an all-year-round basis. The earlier starting hour for application of increased rates before the period of the legislation restriction $(17.00$ - 21.00) has been chosen because there is an increased traffic intensity level of passenger cars on Friday afternoons already after 15.00. 
Increased Friday rates were launched on 1. 2. 2010 and it was the first measure concerning differentiated rates in the EU with the aim of reducing congestions in the highway network.

In the Figure 5 and 6 the average number of domestic vehicles and foreign vehicles on Fridays in the 4th quarter of 2009 and 2010 on tolled network of the Czech Republic is shown. Number of vehicles in the 4th quarter of 2010 is converted to a comparable level of 2009. From these graphs you can see:

- Decrease of number of vehicles in the time period from 15.00 to 21.00

- The difference in the behaviour of domestic and foreign vehicles

In the comparable period (the 4th quarter of 2010) after the introduction of higher tariffs on Friday according to the previous it lead to decrease of vehicles on the tolled road network in the time period from 15.00 to 21.00 :

- $2.8 \%$ of domestic vehicles (registered in the Czech Republic)

- $6.4 \%$ of foreign vehicles

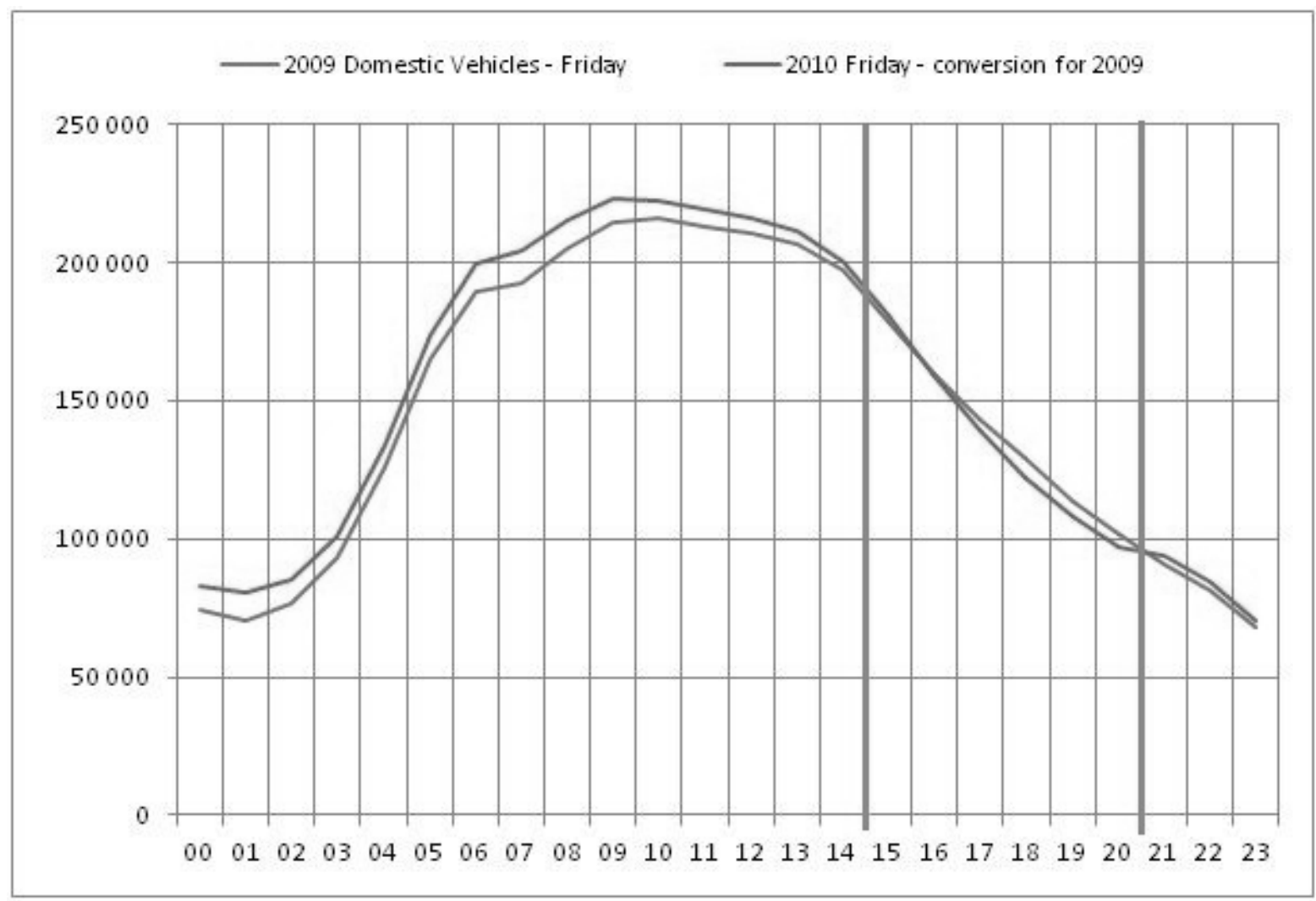

Figure 5: The average number of domestic vehicles on Fridays in the $4^{\text {th }}$ quarter of 2009 and 2010 on tolled network of the Czech Republic.

(Source: DWH of the E-toll System/DWH - Data Warehouse of the E-toll System) 


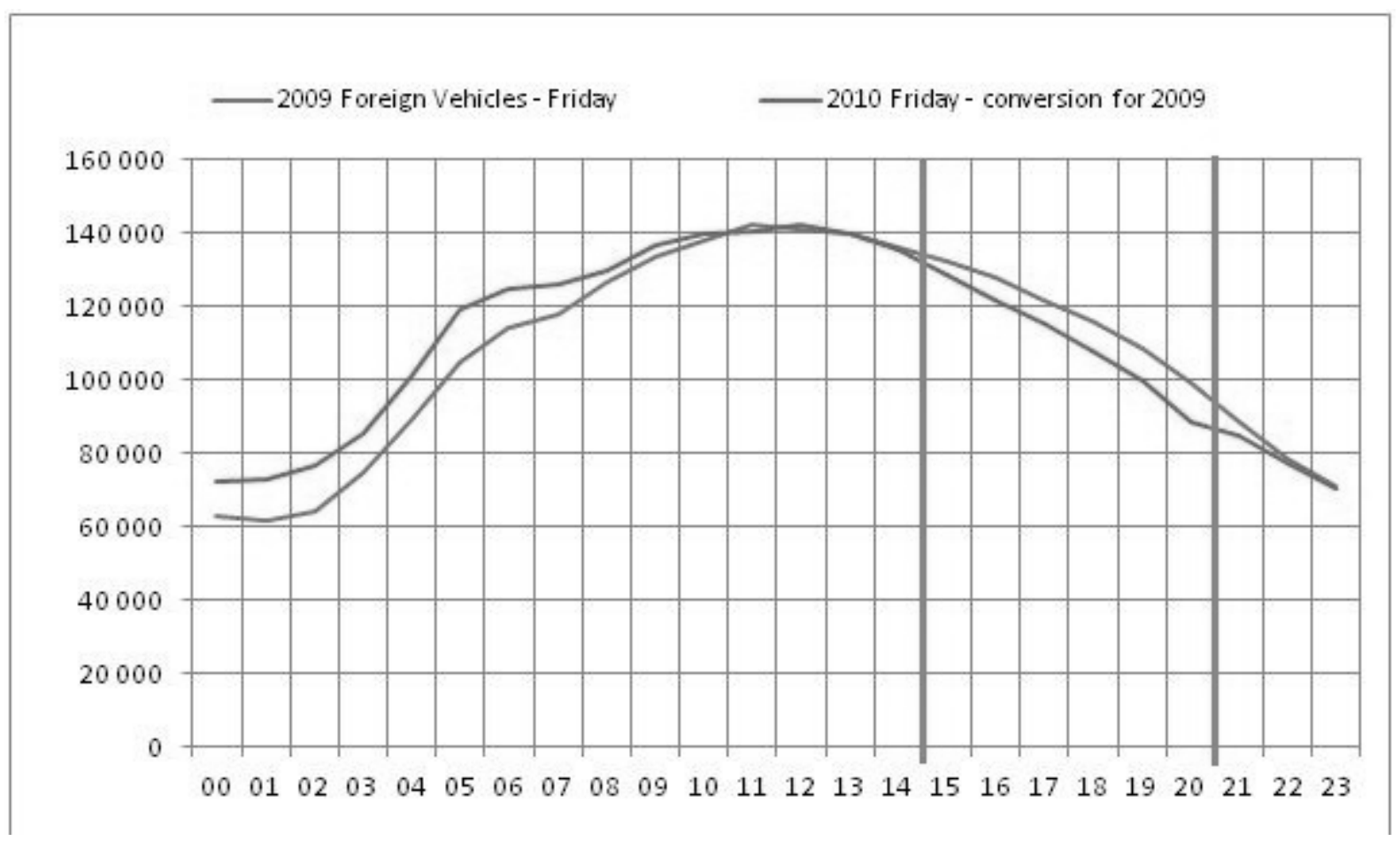

Figure 6: The average number of foreign vehicles on Fridays in the $4^{\text {th }}$ quarter of 2009 and 2010 on tolled network of the Czech Republic.

(Source: DWH of the E-toll System/DWH - Data Warehouse of the E-toll System)

We can say that a significant decrease in trucks and thus a decrease of congestion especially around large agglomerations on the tolled road network in the Czech Republic in Fridays afternoon (15.00 to 21.00) were not found. For domestic vehicles (registered in the Czech Republic) the main reason is probably the end of the work week even the costs are higher. In any case, the whole situation calls for a detailed analysis, because there is (after a very simplified calculation) of approximately CZK 100 million (EUR 4.1 million) an increase in the annual collection of the electronic toll system in the Czech Republic on Friday due to by $50 \%$ higher tariffs in the time from 15.00 to 21.00 . There is also a recognizable effect on the congestion reduction on the tolled highway network in the country.

\section{THE EFFECT OF DIFFERENTIATED TARIFFS OF TOLL SYSTEM ON INCREASING THE NUMBER OF "GREEN VEHICLES"}

The effect of differentiated tariffs of toll system in the Czech Republic on increasing the number of "green vehicles" proved in 2011 and in this year, when the toll rates increased on the $1^{\text {st }}$ of January 2012 for the second time by 25 percent. This change did not affect vehicles with EURO V engines. After the increase of toll rates in the Czech Republic by 25 percent, it should bring by calculation through each emission category a result in increased collection of nearly 20 percent. But the reality is only about ten percent. Many carriers have invested in vehicles meeting the EURO V standards. These vehicles have both lower consumption (by 5-10 percent), and also the carriers save on tolls significantly, because the default toll rate is lower than for vehicles meeting only older emission standards and remained at the level of toll tariffs in 2010.

As a basis for the introduction of higher toll tariffs in 2011 and 2012 an analytical report "Proposal of new toll rates for 2011. Final Report" from the $10^{\text {th }}$ of December 2010 
has been prepared by the Faculty of Transportation Sciences Czech Technical University in Prague and the company Deloitte Advisory s.r.o.

In this report as default assumptions have been defined the following changes in the toll rates made in 2011:

- Introduction of a separate emission class EURO V

- Keeping the EURO III and EURO IV emission classes combined

- Increasing the toll rates applicable to the EURO 0 to EURO IV emission classes by $25 \%$

- Keeping the toll rates applicable to the EURO V emission class at the 2010 level

- Keeping the time differentiation of toll rates during Friday afternoon hours

- The weighted average toll rate shall not exceed the maximum allowable amount derived from the costs of the toll road network and the costs of the toll system.

Subsequently, the average toll rate limit was calculated from the viewpoint of the road costs paid. (Tolls shall be based on the principle of the recovery of infrastructure costs only. Specifically the weighted average tolls shall be related to the construction costs and the costs of operating, maintaining and developing the infrastructure network concerned. The weighted average tolls may also include a return on capital or profit margin based on market conditions - see Article 9 of the Directive - Directive 2006/38/EC) The calculation is based on the following presumptions:

- The constructions costs also took EU subsidies into account, in accordance with Article 9 of the Directive. (Tolls should be based on the principle of recovery of infrastructure costs. In cases where such infrastructures have been co-financed through the general budget of the European Union, the contribution made from Community funds should not be recovered through tolls, unless there are specific provisions in the relevant Community instruments which take into account future toll receipts in establishing the amount of Community co-financing). Whereas the amount of the subsidies allocated towards the construction of roads takes the envisaged toll revenue into account, the authors consider these EU subsidies to be eligible construction costs.

- The operating costs of maintaining and repairing roads were taken into account in full for motorways and expressways, with the appropriate costs for selected tolled sections of class I roads being set proportionally to their length.

\section{Comparison of the newly proposed toll rates with those in surrounding countries}

Those rates lower than those of the said option are highlighted in colour in the following mutual comparison of the toll rates with those in surrounding toll systems. These are namely the rates applicable to vehicles having more than three axles - Table 4 and Figure 7. 
Table 4: Toll rates with those in surrounding countries (2011).

(Bina et al., 2010)

\begin{tabular}{|c|c|c|c|c|c|c|c|c|c|c|c|c|c|c|c|c|}
\hline \multirow{3}{*}{$\begin{array}{l}2011 \\
\text { exchange rate CZK 24,32 } \\
\text { IEUR } \\
\text { Number of axles }\end{array}$} & \multicolumn{16}{|c|}{ Toll rates for $\mathrm{M}$ and $\mathrm{E}$ and vehicles weighing 12 tonnes or more } \\
\hline & \multicolumn{4}{|c|}{ EURO I,II - S1 and S2 exc. PMK } & \multicolumn{4}{|c|}{ EURO III - S3 exc., S2 with PMK } & \multicolumn{4}{|c|}{ EURO IV - S4, S3 with PMK } & \multicolumn{4}{|c|}{ EURO V - S5 and EEV } \\
\hline & 2 & 3 & 4 & 5 & 2 & 3 & 4 & 5 & 2 & 3 & 4 & 5 & 2 & 3 & 4 & 5 \\
\hline Czech Republic & 2,83 & 4,54 & 6,63 & 6,63 & 2,09 & 3,56 & 5,15 & 5,15 & 2,09 & 3,56 & 5,15 & 5,15 & 2,09 & 3,56 & 5,15 & 5,15 \\
\hline Slovak Republic & 4,69 & 4,91 & 5,08 & 5,01 & 4,45 & 4,69 & 4,84 & 4,69 & 4,35 & 4,60 & 4,77 & 4,60 & 4,35 & 4,60 & 4,77 & 4,60 \\
\hline Germany & 6,64 & 6,64 & 6,98 & 6,98 & 5,11 & 5,11 & 5,45 & 5,45 & 4,09 & 4,09 & 4,43 & 4,43 & 3,40 & 3,40 & 3,75 & 3,75 \\
\hline Austria & 4,28 & 5,99 & 8,99 & 8,99 & 4,28 & 5,99 & 8,99 & 8,99 & 3,75 & 5,24 & 7,87 & 7,87 & 3,50 & 4,90 & 7,35 & 7,35 \\
\hline Czech Republic & $100 \%$ & $100 \%$ & $100 \%$ & $100 \%$ & $100 \%$ & $100 \%$ & $100 \%$ & $100 \%$ & $100 \%$ & $100 \%$ & $100 \%$ & $100 \%$ & $100 \%$ & $100 \%$ & $100 \%$ & $100 \%$ \\
\hline Slovak Republic & $166 \%$ & $108 \%$ & $77 \%$ & $76 \%$ & $213 \%$ & $132 \%$ & $94 \%$ & $91 \%$ & $209 \%$ & $129 \%$ & $93 \%$ & $89 \%$ & $208 \%$ & $129 \%$ & $93 \%$ & $89 \%$ \\
\hline Germany & $235 \%$ & $146 \%$ & $105 \%$ & $105 \%$ & $245 \%$ & $143 \%$ & $106 \%$ & $106 \%$ & $196 \%$ & $115 \%$ & $86 \%$ & $86 \%$ & $163 \%$ & $96 \%$ & $73 \%$ & $73 \%$ \\
\hline Austria & $152 \%$ & $132 \%$ & $136 \%$ & $136 \%$ & $205 \%$ & $168 \%$ & $175 \%$ & $175 \%$ & $179 \%$ & $147 \%$ & $153 \%$ & $153 \%$ & $168 \%$ & $138 \%$ & $143 \%$ & $143 \%$ \\
\hline Czech Republic & $100 \%$ & $161 \%$ & $235 \%$ & $235 \%$ & $100 \%$ & $171 \%$ & $247 \%$ & $247 \%$ & $100 \%$ & $171 \%$ & $247 \%$ & $247 \%$ & $100 \%$ & $171 \%$ & $247 \%$ & $247 \%$ \\
\hline Slovak Republic & $100 \%$ & $105 \%$ & $108 \%$ & $107 \%$ & $100 \%$ & $105 \%$ & $109 \%$ & $105 \%$ & $100 \%$ & $106 \%$ & $109 \%$ & $106 \%$ & $100 \%$ & $106 \%$ & $109 \%$ & $106 \%$ \\
\hline Germany & $100 \%$ & $100 \%$ & $105 \%$ & $105 \%$ & $100 \%$ & $100 \%$ & $107 \%$ & $107 \%$ & $100 \%$ & $100 \%$ & $108 \%$ & $108 \%$ & $100 \%$ & $100 \%$ & $110 \%$ & $110 \%$ \\
\hline Austria & $100 \%$ & $140 \%$ & $210 \%$ & $210 \%$ & $100 \%$ & $140 \%$ & $210 \%$ & $210 \%$ & $100 \%$ & $140 \%$ & $210 \%$ & $210 \%$ & $100 \%$ & $140 \%$ & $210 \%$ & $210 \%$ \\
\hline
\end{tabular}

S1 - S4 - Emission classes according to the Guide for determining the emissions classes of heavy commercial vehicles, valid as at 1 January 2009

PMC - Particulate reduction class - standards for additional adjustments reducing the emissions of vehicles

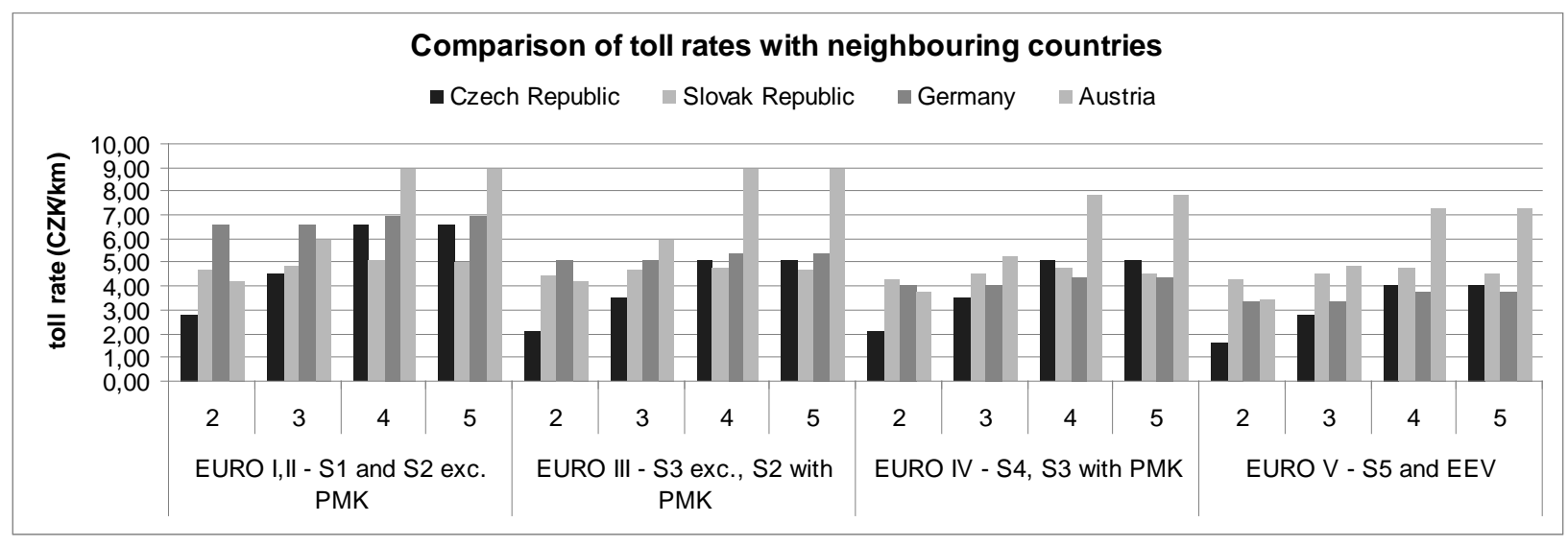

Figure 7: Comparison of toll rates with neighbouring countries (2011).

(Bina et al., 2010)

The same philosophy aimed at supporting green vehicles has also the Federal Republic of Germany, where the amount of toll tariffs strongly supports the introduction of green vehicles with Euro $\mathrm{V}$ and higher engines. In Germany dominate in car fleets of transport and logistics companies modern trucks with a weight from 12 tons with low emissions after eight years from the start of toll. In 2005, the share of vehicles with emission class EURO V was less than one percent of overall driving performance, in mid-2012 it was already 77 percent. The share of the trucks mileage of all three emission classes S0, S1, S2 (EURO I, II) - 
from 36.5 percent in 2005 to 3.7 percent in 2012 decreased proportionally. The share ofemission class S3 (EURO III) in driving performance have decreased from 64.2 percent to 14.0 percent.

In the Czech Republic during the monitored period the share of vehicles in higher emission classes was gradually increasing. The change in emission ratio of traffic volumes reduces the value of weighted average toll. Keeping the toll rates applicable to the EURO $\mathrm{V}$ emission class at the 2010 level meant a significant increase in green vehicles with EURO $\mathrm{V}$ engines, which is shown in Figure 8. On the other hand, this measure meant as previously mentioned that after the increase of toll rates in the Czech Republic by 25 percent, it should bring by calculation through each emission category a result in increased collection of nearly 20 percent. But the reality is only about ten percent.

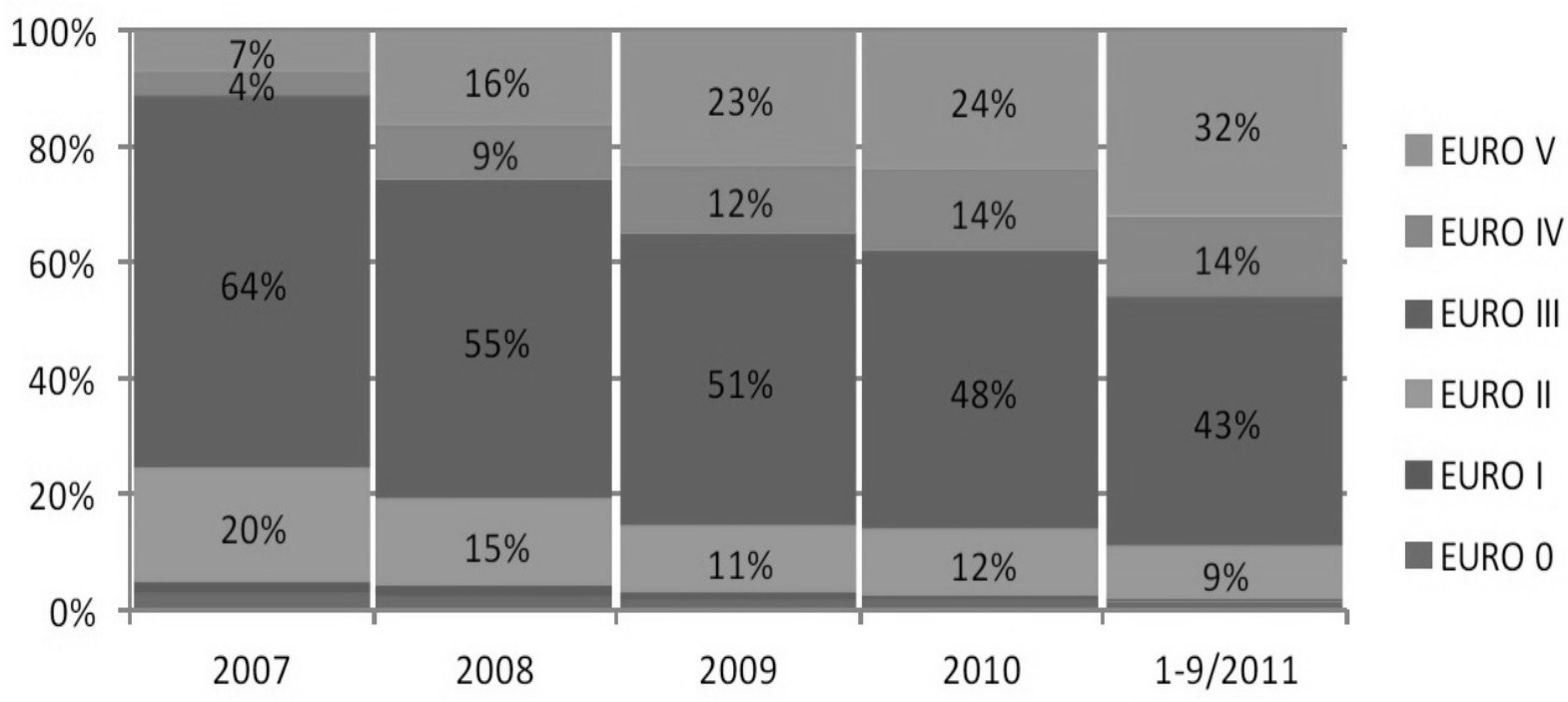

Figure 8: Year over year changes of traffic volume by emission classes of tolled cars in the Czech Republic.

(Source: DWH of the E-toll System)

\section{THE NEW METHODOLOGY FOR DETERMINATION OF TOLL TARIFFS}

In 2011 an analytical team of the Czech Technical University in Prague, Faculty of Transportation Sciences prepared a report on the new methodology for calculating the maximum weighted toll „Report on the Methodology used to Calculate the Maximum Weighted Average Toll prepared in connection with the Notification of the Czech E-Toll System for the European Commission“. This work was a base for The Methodology of calculating the weighted average toll rates in the Czech Republic, of authors Bína, L., Lehovec, F., Nováková H. (all from the Czech Technical University in Prague, Faculty of Transportation Sciences) Vítek, J., Šnévajs, I. (Deloitte Advisory s.r.o.). This work was in 2012 awarded with the prize of the Rector of the Czech Technical University in Prague in the contest of Czech transport construction, Czech transport technology and Czech transport innovation of the year 2011.

In the following text basic directions and parts of the methodology used to calculate the maximum weighted average toll for vehicles subject to the tolling system operated in the Czech Republic, in accordance with the requirements of Directive 1999/62/EC, as amended by 2006/38/EC are described. The methodology is based on the costs incurred on toll roads as of 1978, i.e. 30 years before the introduction of the tolling system 
in the Czech Republic in 2007. The maximum weighted average toll was calculated separately for each year (2007-2017). The overall development of selected parameters of the tolling system in the Czech Republic, including the comparison of the reached or planned weighted average toll with the maximum weighted average toll, is presented in the following table.

\section{Table 5: The overall development of selected parameters of the tolling system in the Czech Republic.}

(Bina et al., 2011)

\begin{tabular}{|c|c|}
\hline Notion & Description \\
\hline Overall allocated investment costs & $\begin{array}{l}\text { Investment (capitalized) costs allocated on heavy goods vehicles above } 3,5 \text { t incurred in } \\
\text { the respective year. Output of the Capex model. Consist of investments in roads and } \\
\text { investments in the tolling system, which includes telematics. EU grants allocated in the } \\
\text { respective year are deducted. These costs are then allocated equally starting in the } \\
\text { year of expenditure and through the depreciation period. }\end{array}$ \\
\hline Allocated investment in the road network & $\begin{array}{l}\text { Construction costs consist of incurred construction costs and costs of structural repairs, } \\
\text { modernization and reconstruction. }\end{array}$ \\
\hline Allocated investment in the tolling system & Capitalized investment costs of acquiring the tolling system are included. \\
\hline $\begin{array}{l}\text { Annual share of overall allocated annual } \\
\text { costs }\end{array}$ & $\begin{array}{l}\text { Sum of all relevant costs for the relevant year, of which the maximum weighted average } \\
\text { toll is calculated in that year. }\end{array}$ \\
\hline Annual share of allocated costs of roads & $\begin{array}{l}\text { Annual shares of allocated investment costs (interest cost), annual costs of } \\
\text { maintenance, and small road repairs. }\end{array}$ \\
\hline $\begin{array}{l}\text { Annual share of allocated costs of the tolling } \\
\text { system and telematics }\end{array}$ & $\begin{array}{l}\text { Operating costs of the tolling system. Also, costs of the tolling system operator, who } \\
\text { belongs to a special division of RSD }{ }^{3} \text { - E-Toll Operator Division (ÜPEM }{ }^{4} \text { ) and activities } \\
\text { of inspection bodies of the Czech Customs Administration that provide enforcement are } \\
\text { also included. }\end{array}$ \\
\hline Total income from toll collection & $\begin{array}{l}\text { Sum of collection/plan/regulations of tolls, both actual and expected. Only for heavy } \\
\text { goods vehicles. }\end{array}$ \\
\hline Toll income of goods vehicles & $\begin{array}{l}\text { Toll collection for tolled goods vehicles, ie goods vehicles with a weight above } 3,5 \mathrm{t} \text {, } \\
\text { separately for motorways and expressways and for tolled sections of } 1 \text { st class roads. }\end{array}$ \\
\hline Length of network and traffic volume & $\begin{array}{l}\text { Contains the basic parameters of the tolled road network, length of tolled sections of } \\
\text { roads and traffic volumes, both actual and expected. }\end{array}$ \\
\hline Length of tolled network & Lengths of tolled road network. \\
\hline $\begin{array}{l}\text { Traffic volume of heavy goods vehicles on tolled } \\
\text { roads }\end{array}$ & $\begin{array}{l}\text { Traffic volumes in millions of vehicle kilometres per year listed according to the type of } \\
\text { road of heavy goods vehicles. }\end{array}$ \\
\hline Annual change in traffic volume & $\begin{array}{l}\text { Annual change in traffic volumes. Influenced by the change in traffic intensity, length of } \\
\text { tolled sections of roads and changes in the scope of tolled vehicles. }\end{array}$ \\
\hline Toll rates and ratios & $\begin{array}{l}\text { Contains the final calculation of maximum weighted average toll and its comparison to } \\
\text { actual or expected weighted average toll. }\end{array}$ \\
\hline Maximum weighted average toll & Calculated maximum weighted average toll that should not be exceeded. \\
\hline Weighted average toll & $\begin{array}{l}\text { Calculated actual or expected weighted average toll that is counted as a share of } \\
\text { the collected toll to traffic volumes. }\end{array}$ \\
\hline $\begin{array}{l}\text { Share of tolling income on allocated costs of the } \\
\text { network }\end{array}$ & Percentage share of toll collection on allocated costs of network. \\
\hline Allocated costs per $1 \mathrm{~km}$ of tolled section & Allocated costs per $1 \mathrm{~km}$ of tolled section of a road. \\
\hline Income per $1 \mathrm{~km}$ of tolled section & Income from toll collected per $1 \mathrm{~km}$ of tolled section of a road. \\
\hline $\begin{array}{l}\text { Share of allocated costs of the tolling system to } \\
\text { incomes from the tolling system }\end{array}$ & $\begin{array}{l}\text { Expresses what the share of costs of the tolling system on the total collected } \\
\text { is. }\end{array}$ \\
\hline
\end{tabular}

Based on EC Directive 1999/62/EC as amended by 2006/38/EC, Annex III, the maximum weighted average toll shall be calculated from the introduction of the tolling system in the Czech Republic in 2007 to 2011, with an outlook until 2017.

Under these assumptions, in period from year 2010 till 2017, weighted average tolls of heavy goods vehicles on motorways, expressways and tolled 1st class roads are always 
below the maximum weighted average toll. Comparison of the maximum weighted average tolls to weighted average toll is in the Figure 4.

\subsection{Method of determining the costs of road infrastructure}

Either the perpetual inventory method (PIM) or the synthetic method can be used to determine the costs of roads. Based on the acquired data series of incurred costs, the PIM method was preferred mainly owing to the possibility of predicting further development of toll rates and owing to the possibility to quickly evaluate the impacts of future investment strategies on the size of toll rates.

- Synthetic method: The synthetic method is based on the current amount of assets and depreciation periods of the infrastructure. However, determining the initial value of the assets requires a significant share of qualified estimates, which is why this method was not chosen.

- Perpetual Inventory Method (PIM): The PIM method is based on the knowledge of annual costs incurred in the past on the road network. The advantage of this method is that toll rates in the future can be modeled easier, using the trends of the variables monitored.

- Selection of the method used: All available information was assessed before the method to calculate the average weighted toll rate was chosen. Historical data for the 1990-2000 periods and a model of price norms from 2008, which were used to determine the value of the road network completed between 1978 and 1989, were available. For the period of 2001 and after, the data is already available in the required structure.

6.2 Historic data until 2010

Data on costs incurred on the construction, maintenance and repairs of motorways, expressways and 1st class roads was obtained from the sources stated below:

- Information provided by the Ministry of Transport of the Czech Republic

- List of EU grants between 2002 and 2010, with outlook for 2013.

- Information provided by the Road and Motorway Directorate of the Czech Republic (hereinafter “RSD”):

- Historical series of costs of construction, maintenance and repairs of roads and motorways for 1990-2000 published on www.rsd.cz;

- Annual accounts data between the RSD and the State Fund for Transport Infrastructure (SFDI) for 2001-2010. The review of grants is based on RSD accounting, which contains the actual use of costs in individual years;

- RSD annual reports.

- Information provided by the Faculty of Transportation Science of the Czech Technical University in Prague (“CTU”):

- Price norms of construction of roads 2008 which were prepared for the Ministry of Transport of the Czech Republic

- Information on the transfer price indexes of construction sites:

- Transfer price indexes of construction sites from 1971 to 2009 (Institute of rationalization of the construction industry, URS Prague, 2009).

- Information on the volume of traffic on motorways and roads obtained from the data warehouse of the tolling system: 
- Traffic volumes on the network of motorways, expressways and selected sections of 1st class roads for 2007-2010;

- Planned toll amount for 2007-2010;

- Division of traffic volumes according to weight categories of vehicles and emissions groups for 2010;

- Based on the 2010 national transport census, the estimate of the future development of traffic intensity, toll rates and length of toll roads was prepared for the 2011-2017 period.

- Information on the volume of traffic on 1st class roads obtained from the national transportation census in 2010:

- Nationwide transport volumes on 1st class roads.

- Information on damage caused by vehicles on the state of the roads:

- Report by the Transport Research Centre (CDV), „Analýza trendů silniční nákladní dopravy v letech 1995-2003, březen 2005“.

\subsection{Expected future period from 2011 to 2017}

Estimations for the period after 2010 were prepared based on the following data:

- 2011-2013:

- SFDI budget for 2011 with outlook for 2012 and 2013, which has been passed by the parliament.

- 2014-2017:

- Extrapolation of historical trends in the future development of costs spent on the road infrastructure and planned new toll rates.

Regular annual update of outlook of size of maximum weighted average toll is expected.

\subsection{Costs of construction - Motorways and expressways}

a) Origin of construction costs

The PIM method requires knowledge of the lifetime of construction costs that were incurred annually and completed at least 30 years before 10 June 2008. Thus, the relevant year is 1978 because the tolling system in the Czech Republic was launched on 1 January 2007 (see Article 3) of Directive 1999/62/EC as amended by 2006/38/EC).

Given the fact that accounting reports were not available for such a long period, the following method was chosen:

- Costs of construction between 1978 and 1989 are derived from the price norms by the CTU, which were prepared to assess the basic costs of construction of the road network. $6 \%$ of the costs of the project work were added to the prices. Further evaluation was not conducted. Price norms are prepared at the 2008 price level. Prices of roads between 1978 -1989 were then determined using transfer price indexes of construction objects set by an engineering and consulting organization (URS Prague, see Annex 14.3).

- Construction costs between 1990 and 2000 were taken by RSD from publicly available sources. As the costs were stated in aggregate, they were allocated to motorways, expressways and toll sections of 1 st class roads.

- Construction data for the 2001-2010 periods was obtained from billing documents between RSD and SFDI that contain detailed information (in contrast to the previous data). 
- Construction costs for 2011-2013 were received from the SFDI budget for 2011, which also contains a mid-term outlook for 2012 and 2013.

- Construction costs for 2014 - 2017 were based on experts estimate.

- Incurred investment costs are allocated equally throughout the 30-year depreciation period.

\section{b) Method of allocating construction costs}

Construction costs were distributed and then allocated to toll roads as follows:

- The 1978-1989 construction costs were fully allocated from the price norms on motorways and expressways. Construction costs on 1st class roads were not taken into consideration in this period.

- The 1990-2003 construction costs are stated in aggregate for motorways, expressways and 1st class roads. By the method presented above, the construction costs of $1^{\text {st }}$ class roads were allocated gradually at $36 \%$, using the same average rate as in the case of 2001-2010 construction costs.

- The 2001-2010 construction costs were distributed according to the basis for recognition between RSD and SFDI.

- The 2011-2013 construction costs were allocated based on the SFDI budget, pass.

- Construction costs for 2014 - 2017 were allocated on their previous trends.

\subsection{Other costs}

In the calculation were included: maintenance costs, investment costs of the tolling system, investment costs of telematics, operating costs of the tolling system and telematics, financial costs, EU grants.

\subsection{Calculation of the maximum weighted average toll}

This section presents the method of calculating the maximum weighted average toll by Directive (see Article 2, paragraph ba) and Article 7, paragraph 9 of the Directive11). "Directive" means EC Directive/62/EC as amended by 2006/38/EC.

Toll collection cannot exceed the costs incurred on construction and operation of tolled roads and on the construction and operation of the toll and ITS system, including dissolved investment costs for the considered period:

INC $<=$ Ca

INC - Income of toll (CZK) - toll collection in the period, $\mathrm{Ca}$ - Cost allocated to heavy vehicles (CZK) - construction, operating and financial costs allocated on tolled roads and the respective traffic volumes of tolled goods vehicles above 3,5t

a) Method of calculating the maximum weighted average toll

In accordance with Article 2., Annex III. of the Directive, the weighted average toll is calculated as a division of the allocated costs of the road network and tolling system on the traffic volume on the respective road expressed. In compliance with the Directive the buses are not included in the maximum weighted average toll calculation. 
Maximum weighted average toll allocated on heavy goods vehicles is set by the following ratio:

\section{$\mathbf{R m a x}=\mathbf{C a} / \mathrm{Vh}$}

Rmax - Maximum Toll Rate $(\mathrm{CZK} / \mathrm{km})$ - Maximum weighted average toll $\mathrm{Ca}$ - Cost allocated to heavy goods vehicles ( CZK) - costs of roads and toll system allocated to vehicles subject to the toll based on the ratio of traffic volume of tolled vehicles to the overall traffic volume on the toll road.

Vh - Traffic Volume (vehicle kilometre) is the traffic volume of heavy goods vehicles.

\section{b) Counted costs}

The types of costs that can be counted into the calculation of the maximum weighted average toll consist of:

- Investment costs that are counted for the respective year in a size based on the period of depreciation. These include costs of construction, costs to purchase land, costs to conduct an archaeological survey, cost of project and inspection activities, costs of modernization of roads, telematics, and other related costs. EU grants are deducted from the investment costs depending on how they are used and they are eventually deducted appropriately in the respective programming period.

- Operating costs, which include the costs of maintenance and operation of roads, tolling system, telematics, and interests of loans, are counted all in the respective year.

- Costs of the toll system include investment costs on its construction and further expansion on motorways and expressways and they include also operating costs until 2016 when the contract with the present provider of services terminates.

Because planned costs are set by the SFDI budget for individual years, the discount rate and inflation are not included in the calculations and the maximum weighted average toll is calculated repeatedly for each year.

Costs included in the calculation of the maximum weighted average toll according to Article 2, Annex III. of the Directive:

$\mathbf{C}=\mathbf{I}-\mathbf{G}+\mathbf{E}+\mathbf{T}+\mathbf{M}+\mathbf{F}+\mathbf{O}$

$C$ - Total Costs (CZK) - total costs included in the calculation of the maximum weighted average toll before allocation

I - Investment Costs (CZK) - annual share of construction costs on the road network, distributed equally along the period of depreciation starting in the year of expenditure

$G-E U$ Grants (CZK) - annual share of received EU grants

$E$ - E-toll Costs (CZK) - annual share of investment costs on the tolling system, distributed equally along the amortization period starting in the year of expenditure

$T$ - Telematic Costs (CZK) - annual share of investment costs on road telematics on motorways, distributed equally along the period of depreciation starting in the year of expenditure

$M$ - Maintenance (CZK) - annual costs of repairs and maintenance, including operating costs of the tolling system and telematics

F - Financial Cost (CZK) - annual financial costs - interests of credits

$O$ - Operational Costs (CZK) - annual operating costs of the road network operator 
c) Allocation of costs according to Annex III., Point 4. of the Directive

Both groups of costs stated above were further allocated:

- In proportion to the traffic volumes of tolled vehicles to the overall traffic volume which includes also vehicles that are not subject to toll. Traffic volumes were adjusted by the coefficient of allocation and then the coefficient of allocation $\mathrm{Kv}$ was calculated, which takes into account the level of road network damage by the operation of heavy goods vehicles;

- Owing to the reasons of known costs of the total length of tolled roads, the costs of maintenance were allocated in proportion of the tolled and total length of respective class of road by the coefficient Ks. The proportion of the traffic volume on tolled part and total roads length was used for allocation of investment, reconstruction, modernization and repair.

\section{Incurred costs are allocated on tolled heavy goods vehicles and on tolled lengths of roads:}

$\mathbf{C a}=\mathbf{C} \times \mathbf{K v} \times \mathbf{K s}$

$\mathrm{Ca}-$ Cost Allocated to heavy goods vehicles

$C$ - Total Costs $(C Z K)$ - total costs that are included in the calculation of the maximum

weighted average toll rate before allocation

$\mathrm{K} v$-coefficient of cost allocation on tolled heavy goods vehicles

Ks - coefficient of reduction of toll road length or their traffic volume

\section{CONCLUSION}

The paper contains the overview of the basic specifications and activities connected with the implementation of the electronic toll system in the network of highways and other roads of the Czech Republic. The implementation of this system is an example of an indirect PPP model of financing, in which the investment and operating payments of the system are covered from the collected toll. The roll-out of the system to cover the full scope of the road network of the Czech Republic requires extensive cooperation among a number of entities participating in the implementation and operation of the system. It is also necessary to mention the cooperation of the research capacities of the Faculty of Transport of the Czech Technical University in Prague, particularly the FT CTU Expert Group of the Minister of Transport. With regard to the pressure on reduction of congestions, the proposal for differentiated toll during Friday afternoon hours when the traffic intensity level substantially rises in the highway implies recognizable effect on congestion reduction on the toll highway network in the Czech Republic. In any case, the whole situation calls for a detailed analysis, because there is (after a very simplified calculation) of approximately CZK 100 million (EUR 4.1 million) an increase in the annual collection of the electronic toll system in the Czech Republic on Friday due to by 50\% higher tariffs in the time from 15.00 to 21.00 .

In the end of the paper principles and results of a new methodology for calculating the weighted average toll rates in the Czech Republic are described. The methodology has been applied in the revision of this calculation by the European Commission in 2011. 


\section{REFERENCES}

Arnold, R., et al., 2010. Reducing Congestion and Funding Transportation Using Road Pricing in Europe and Singapore. Research Report FHWA_PL-10-030. Washington, DC: FHWA.

Balducci, P., et al., 2011. Costs of Alternative Revenue-Generation Systems. NCHRP Report 689. Washington, DC: Transportation Research Board.

Bína, L., Lehovec, F., Moos, P., Nováková, H., Karlický, P., Vítek, J., Lomská, D., Šnévajs, I., Apfelthaler, J., 2011. Report on the Methodology used to Calculate the Maximum Weighted Average Toll prepared in connection with the Notification of the Czech E-Toll System for the European Commission. Research project for the Ministry of Transport of the Czech Republic.

Bína, L., Lehovec, F., Moos, P., Skurovec, V., Horák, T., J., Lomská, D., Šnévajs, I., Apfelthaler, J., 2010. Proposal of new toll rates for 2011. Research project for the Ministry of Transport of the Czech Republic.

Council of the European Union, Land Transport, 2009. Proposal for a Directive of the European Parliament and of the Council amending Directive 1999/62/EC on the charging of heavy goods vehicles for the use of certain infrastructures.

Černý, V., 2008. Zavedení elektronického mýta v České republice. Silniční obzor, vol. 69, no. 5. ISSN 0322-7154. (in Czech)

Donath, M., et al., 2009. Technology Enabling Near-Term nationwide Implemantation of Distance based Road User Fees, Final Report. Minneapolis, MN: Inteligent Transportation Systems Institute, University of Minnesota,

Durden, D. J., 2010. Funding Texas Highways for the Next 20 Years. Texas Civil Engineer, vol. 81.

European Parlament, Policy Department B, Structural and Cohesion Policies, 2008. Study Pricing Policy for Road Freight Transport in EU Members States and Switzerland.

Feix, K., 2009. Czech electronic toll collection - two and half years of experiences. 16 p. Praha: Kapsch Telematic Services.

Moos, P., Bína, L., Lehovec, F., Skurovec, V., Horák, T., et al., 2009. Analytická studie navýšení mýtného $v$ době pátečního omezení jízdy kamionů jako opatření ke snížení jízd kamionu nad 7,5 $t$ v pátek od 15.00 do 18.00 [Analytical report for increasing toll rates in Friday's truck over 7,5 t operation restriction from 3 p.m. to 18 p.m.]. Research project for the Ministry of Transport of the Czech Republic. (in Czech)

Slone, S., 2009. Vehicle Miles Travelled Fees, A Trends in America. Special Report. The Council of State Government. 
Smith, D. R., Chang-Albitres, C., Stockton, W. R., Smith, C. R., 2004. Estimating Revenues Using a Toll Viability Screening Tool. FHWA Report TX-05/0-4726-1. Texas: Texas Transportation Institute, College Station.

Taothon, S., Jiwattanakulpaisarn, P., Kanitpong, K., 2012. An Empirical Analysis of Success and Failure Factors for Public-Private Partnerships in Toll Road Investments. Paper No. 11-3586. Washington, DC: Transportation Research Board. 